\title{
CIVIL SOCIETY AND ADULT EDUCATION PROVISION
}

\author{
http://dx.doi.org/10.5902/2318133834863
}

\author{
Thiago Bogossian ${ }^{1}$
}

\begin{abstract}
This paper aims to discuss to what extent civil society organisations have impacted on the nature of adult education provision. It argues that civil society is a medley with distinct institutions with different ideologies, either pushing adult education to the needs of the labour market or to an agenda of emancipation and freedom. Drawing from examples of three distinct countries - Sweden, South Africa and the United States - it concludes that civil society has shaped much of adult education paradigm throughout history and it continues to be a privileged site of struggle to counter-hegemonic learning take place aiming for more democracy and equality.
\end{abstract}

Key-words: civil society, adult education, lifelong learning.

\section{SOCIEDADE CIVIL E FORNECIMENTO DE EDUCAÇÃO DE ADULTOS}

Resumo

Pelo artigo busca-se discutir em que medida organizações da sociedade civil impactaram na natureza do fornecimento de educação de adultos. Argumenta-se que a sociedade civil é uma mistura de instituições com ideologias distintas, ora empurrando educação de adultos para as necessidades do mercado de trabalho, ora para uma agenda de emancipação e liberdade. Com base em exemplos de três países distintos - Suécia, África do Sul e Estados Unidos - conclui-se que a sociedade civil moldou boa parte do paradigma da educação de adultos ao longo da história e continua sendo um locus privilegiado de luta por uma educação contra-hegemônica que busca mais democracia e igualdade.

Palavras-chave: sociedade civil, educação de adultos, aprendizagem ao longo da vida.

${ }^{1}$ University of Glasgow, UK. E-mail: thiagobogossian@gmail.com.

\begin{tabular}{l|c|c|c} 
Regae: Rev. Gest. Aval. Educ. & Santa Maria & v. 8 & n. 17
\end{tabular} 


\section{Introduction}

ifelong learning can be expressed in many different ways, from acquisition of abilities to critical thinking for social change. The development of new work skills, for example, in a world which is constantly changing is one of its visages. Employees from factories and offices have to persistently adapt to the progressive transformation of the techniques required by their employees so they can secure their jobs. Another aspect of lifelong learning, however, can occurs inside social movements or community institutions through debates about that same constantly changing world while propose and struggle for changes in wider structures of the society. While the first can be seen as a predominantly market-oriented paradigm, much centred on the individual, the second presupposes a dialectical relationship between learning and social change, with more collective features.

This introduction is conceptual to help didactically differentiate paradigms that conform adult education but, in reality, most societies use both standards with more emphasize on one than another depending on the power of organisations who support practices and policies. If major international corporations are robust and can influence policies and government decisions, they can shape adult education towards vocational training and preparation for work, what English and Mayo (2012, p. 77) call "adult education serving the economy", mainly through human capital theory. Hoff and HicklingHudson (2011) go in the same direction when point out that "neoliberal globalisation marginalised the social transformation message of adult education and foreground its technical/instrumental focus on preparing people for seeking jobs" (p. 188).

However, other forces of groups from below, some of them called marginalized groups or minorities, such as but not restricted to working class, environmentalists, women, ethnic groups or LGBTs can speak their voice through social movements or civil society organisations and propose a different kind of adult education provision. Therefore, the objective of this work is to briefly examine impacts of civil society organisations on the nature of adult education provision. It plans to understand if some of the major features that are commonly connected with adult education practices today were affected by civil society organisations in different countries. It is assumed that educational work throughout civil society can challenge relations of hegemony inside the state, which refers to some of Gramsci works (English; Mayo, 2012, p. 30-32). Thus, this text starts by briefly presenting the concept of civil society and moves to analysing its impacts on adult education provision through some international examples, which will be the evidences for the purposes of this paper. In the end, it is discussed if the samples can address a more general pattern and briefly presented some of the contemporary challenges.

\section{Development}

Civil society is generic name for free associations between individuals with similar objectives where they can discuss and suggest directions for social change, either in a progressive or a conservative way. Thus, it is part of participation of the citizens in democratic and public life. Civil society organisations include groups who are both distinct from the state and market forces such as but not restricted to nongovernmental organisations, churches, trade unions, voluntary agencies, cultural groups and popular movements. Although they are permanently threatened of being colonized or invaded by 
these forces, it is expected that they have relative independence and their existence is part of a health and vigorous democratic system (Hoff and Hickling-Hudson, 2011; Crowther and Martin, 2010). Although civil society groups are generally linked with marginalized groups, in this broad definition, United States' Tea Party, Brazil's Landless Workers' or Greenpeace can all be considered parts of the civil society and each of them has his own propose for adult education policies according to their ideology and political program.

The renew interest in civil society is both related to the collapse of socialist regimes and the feeling of lack of representability of traditional movements such as trade unions and political parties (Murphy, 2001; Crowther; Martin, 2010). Considering that civil society is not necessarily good or bad, it can be perceived as an arena of dispute where different social groups can contest their positions, according to Gramsci tradition (English and Mayo, 2012, Crowther and Martin, 2010). "Civil society is precisely the special field of action of the intellectuals", says Gramsci (cited in Hobsbawm, 2011, p. 323), pointing that intellectuals are not a special category of society but a social function. According to his perspective, this means the struggle of classes are not only economic clashes between workers and industrialists either inside the factory or for the means of production but also disputes of hegemony of cultural forces within society such as schools, trade unions and churches. The more organized social class can prevail their ideology while subjugate the other.

Gramsci's argument is useful to understand how organised groups can drag society spheres such as education, health, environment, housing or public transportation towards their interests. As Hoff and Hickling-Hudson (2011) discuss, civil society is a medley with different agendas depending on the ideological position of actors, meaning that "both neoliberal ideas and counter-hegemonic resistance are evident in global civil society" ( $p$. 189). Therefore, an environmentalist group, for example, can promote debate about usage of fossil fuels, encourage mass public demonstrations against oil companies or create media campaigns supporting green transportation. These practices are not only powerful tools of informal education but also construct ways of pressure in the state to execute their demands. Thus, to understand in which extent civil society changes the nature of the field of adult education, it is appropriate to indicate some experiences in different countries that suit as evidences to support this argument. For these purposes, it is hereafter described particular features of three different countries regarding practices of civil society organisations that shape the nature of adult education provision at both local and global level debates.

In Sweden, what was at first group meetings to read and interpret the Bible postReformation period that shared reading materials and reflective attitudes as tools for learning turned into a space for critical discussions about the world and our presence on it (Gougoulakis, 2016). According to this author, these were the roots for working-class movement build and spread community-based learning of equality, justice, solidarity, democratic process in this nation and also develop abilities of lead, organize and exercise political activities. He also notices the current result of Sweden being a country with strong social justice system, radical democracy and freedom is partly consequence of the strong popular adult education inside working class movements throughout its history (Gougoulakis, 2016). 
In the United States, two revolutionary socialist organisations consider the importance of awareness of oppressions and raise of consciousness within mass movement of working class (Holst, 2004). League of Revolutionaries for a New America LRNA -, for example, splits its education committee into propaganda and education, although both are related for the political formation of the revolutionary class. From the production of a monthly newspaper to a monthly radio broadcast as well as a regular update of the organisation's website, all these initiatives are fundamental to develop critical thinking amongst workers towards social change (Holst, 2004).

In South Africa social movements who fought for freedom and liberation during the apartheid period were allies despite class, geographic or racial backgrounds. According to Walters (2005), learning within social movements was conscious: radical democratic practices were ways to enhance members' awareness of the country's situation as well as developing collective capacities and leaderships. In addition, most knowledge was built inside social movements through debates over agendas, campaigns, meetings and exchanges of strategies and tactics. She also finds they were inspired both by Gramsci and Freire because learned by doing was central part of their practice (Walters, 2005, p.59).

Instead of being singular and isolated experiences, these cases are examples of general processes in other societies. These studies reveal the persistent idea that civil society plays an important role in shaping the nature of adult education towards emancipation, critical thinking and social change in different countries. They introduced patterns such as development of local communities' empowerment, importance of nonformal and informal education, citizenship, horizontality, overcome of class and gender inequities and radical democratic participation in adult education agenda which would otherwise probably be ignored if it was exclusively driven by market forces.

Civil society can also be an arena for challenging Eurocentric perspectives, as discussed by Hall and Tandom (2017). They find that the creation of universities in the western world limited access to knowledge and control other forms of knowledge more nature and local-based and less scholarly by a few elite. The civil society uprising is a favourable circumstance to confront and overcome this excluding structure towards multiple epistemologies and knowledge democracy. In this perspective, the adult education must be a site of learning in non-colonial terms, which might include text, image, poetry, numbers, story, drama, ceremony and meditation (Hall; Tandom, 2017, p. 13).

\section{Conclusions}

If it still not possible to say that critical adult education for social change is the majority, since "learning to earn" is the hegemonic one (English; Mayo, 2012, p. 77), there are many good projects in this direction. Inspired by Freire's (1987) ideas, these programs are committed to transformation through an intense participation of individuals in the processes of learning as subjects, not objects. Education for participatory democracy and freedom, dialogue between structured and popular knowledge, recognition of individual's experience, respect and relationship between theory and practice - praxis - are some thoughts from Freire who inspire adult education practices globally. Although some economic groups still try to draw it for their own interests, it seems that this field is internationally robust enough to maintain some of its practices within civil society roots and 
linked to social change paradigms. The outcome of this debate is that civil society both shaped much of adult education paradigm throughout history and it continues to be a privileged site of struggle to counter-hegemonic learning take place aiming for more democracy and equality.

Finally, as the world becomes more interconnected and the means of transport and communication compress time-space (Harvey, 1989), we see the rise of an idea of global civil society, as explored by Hoff and Hickling-Hudson (2011). According to them, globalisation increased disparities and the state's mechanisms to deal with these problems are being undermined. The authors call for creation of international networks through nongovernmental organisations who promote adult education to advance social justice and influence social development in a global scale. Proposing similar approaches to the postcolonial frameworks discussed by Hall and Tandom (2017) above, Hoff and HicklingHudson (2011) propose a holistic perspective to overcome injustice and inequality considering multidimensionality, social development and radical democratic participation of citizens, which is also endorsed by English and Mayo (2012).

This globalized time that we are living on today creates the opportunity to think about changes in configurations of the societies around the globe with a different perspective. Since many of the threads we need to face nowadays such as climate change, global inequality or knowledge ethnocentrism require an international approach, the role of civil societies overflow their previous territories. To think about new strategies to face these issues while promote bonds with similar movements in other nations is part of new challenges for both adult educators and civil society's groups.

\section{References}

CROWTHER, James; Martin, Ian. Adult education and civil society. International Encyclopedia of Education. Third edition, 2010, p. 191-197.

GOUGOULAKIS, Petros. Popular adult and labor education movement in Sweden: history, content, pedagogy. International Labor and Working-Class History, 90, 2016, p. 12-27.

ENGLISH, Leona; Mayo, Peter. Learning with adults: a critical pedagogical introduction. Rotterdam: Sense Publishers, 2012.

FREIRE, Paulp. Pedagogia do oprimido. Rio de Janeiro: Paz e Terra, 1987.

HALL, Buddl; Tandon, Rajesh. Decolonization of knowledge, epistemicide, participatory research and higher education. Research for All, v. 1, n. 1, 2017, p. 6-19.

HARVEY, David. The postmodern condition. Oxford: Oxford University Press, 1989.

HOBSBAWM, Eric. How to change the world: reflections on Marx and marxism. Yale: University Press, 2011.

HOFF, Lutz; Hickling-Hudson, Anne. The role of international non-governmental organisations in promoting adult education for social change: a research agenda. International Journal of Educational Development, 31, 2011, p. 187-195.

MURPHY, Mark. The politics of adult education: state, economy and civil society. International Journal of Lifelong Education, v. 30, n. 5, 2001, p. 345-360.

WALTERS, Shirley. Social movements, class and adult education. New Directions for Adult and Continuing Education, n. 106, 2005, p. 53-62. 
Thiago Bogossian has a bachelor in Geography and Master's in Education from Universidade Federal Fluminense and is currently reading for an International Master in Adult Education for Social Change at a consortium among University of Glasgow, University of Malta, University of Tallinn and Open University of Cyprus. Orcid: https://orcid.org/0000-0002-4679-2248.

Address: School of Education, University Avenue, Glasgow, Scotland, G12 8QQ. E-mail: thiagobogossian@gmail.com.

Recebido em 19 de setembro de 2018. Aprovado em 2 de dezembro de 2018.

(c) $(\mathrm{P}$ 